\title{
Management by Totemization: Whale Symbolism and the Anti-Whaling Campaign
}

\author{
ARNE KALLAND ${ }^{1}$
}

(Received 18 November 1991; accepted in revised form 22 June 1992)

\begin{abstract}
The anti-whaling campaign has been with us for about two decades by now, and - not surprisingly - the arguments against whaling have changed during these years. The ecological argument that the whales are endangered is losing ground as it becomes clear that the stocks of some species of whales can sustain regulated harvest. Therefore, during the last few years more and more people have argued against whaling on moral and ethical grounds. Whales have come to hold a special place in the animal kingdom.

Three related themes are addressed in this paper. First, the process by which whales are turned into a symbol is analyzed. By combining characteristics found in a number of different whale species, a picture of a "super-whale" has emerged. Second, it is argued that whales have such potential as symbols because 1) whales are anomalous animals difficult to categorize, 2) they live in salt water, which symbolizes the ultimate purity, 3) they have a long history, and 4) they have qualities that we would like to see in our fellow human beings. It is argued that whales are turned into totems, thus dichotomizing mankind into "good guys" (protectors of whales) and "bad guys" (whalers). Finally, it is shown that by turning whales into totems and imposing an indefinite moratorium on whaling, the resource base of many coastal ccmmunities in northern Norway has been narrowed significantly, which has serious implications for the viability of these communities.
\end{abstract}

Key words: whales, whaling, management, protectionism, symbolism, totem, rhetoric, impact, northern Norway

RÉSUMÉ. Les campagnes contre la chasse à la baleine existent depuis plus de 20 ans, et il n'est pas surprenant que les arguments aient changé au cours des années. L'argument écologique voulant que les baleines soient menacées est en train de perdre du terrain car il devient évident que le stock de certaines espèces peut supporter une prise réglementée. Par conséquent, au cours des dernières annees, de plus en plus de gens se sont opposés à la chasse à la baleine d'un point de vue moral et éthique. Les baleines en sont venues à occuper une place privilégiée dans le règne animal.

Cet article aborde trois thèmes qui sont reliés. En premier lieu, on analyse le processus par lequel les baleines sont transformées en symboles. De la combinaison des caractéristiques d'un certain nombre d'espèces différentes est ressortie l'image d'une «super-baleine». On soutient ensuite que le potentiel symbolique des baleines vient de ce qu'elles 1) sont des animaux sortant de l'ordinaire, difficiles à classer, 2) vivent dans l'eau salée, qui symbolise la pureté absolue, 3) ont une longue histoire, et 4) ont des qualités que l'on aimerait retrouver chez nos confrères humains. On soutient que les baleines sont érigées en totems, ce qui divise l'humanité en *bons» (qui protègent les baleines) et en «méchants» (qui les chassent). On démontre finalement que la transformation des baleines en totems et l'imposition d'un moratoire d'une durée indéterminée ont réduit de façon significative la base de ressources de nombreuses communautés côtières de la Norvège septentrionale, ce qui a de sérieuses conséquences pour la viabilité de ces communautés.

Mots clés: baleines, chasse à la baleine, gestion, protectionnisme, symbolisme, totem, rhétorique, impact, Norvège septentrionale

Traduit pour le journal par Nésida Loyer.

A large proportion of the inhabitants of the northern regions still depends on renewable natural resources - such as fish, marine and terrestial mammals, plants, and birds - for their livelihood. The availability of many of these resources is highly unpredictable in that they vary greatly between seasons and from one year to the next, forcing people to exploit several resources in order to make sustainable communities. Defining a niche as "the place of a group in the total environment, its relation to resources and competitors" (Barth, 1969:363), it can be argued that whalers in Alaska (Alaska Consultants Inc., 1984), Canada (Wenzel, 1991), Greenland (Kapel and Petersen, 1982), Iceland (Pálsson, 1992), and Norway (ISG, 1992) typically exploit multispecies niches, which give people flexibility in their adaptations to the environment.

Today this flexibility is challenged from many quarters. An increasing number of people and institutions claim access to the Arctic, leading to pollution and other disturbances that have long-lasting effects on this fragile environment. This has, among other things, caused depletion of marine resources, with restrictions imposed on access as a result. Although this leads to a loss of flexibility, and thus greater vulnerability in the future, such restrictions are in general accepted if people used to harvesting these resources are convinced that the restrictions are ecologically sound. But whalers have never accepted the anti-whalers' argument that a total moratorium on all commercial whaling had to be imposed because of overexploitation of the whale stocks.
The ecological argument that the whales are endangered is losing ground, however, and the Scientific Committee of the International Whaling Commission (IWC) and the U.S. Marine Mammal Commission have made it clear that some of the 75-odd species of whales can sustain regulated harvest (letter dated 5 December 1991 from the executive director of the Marine Mammal Commission, John R. Twiss, to the U.S. commissioner to the IWC, John A. Knauss). Nevertheless, the anti-whaling campaign continues unabated, albeit with somewhat new arguments. "Now is an appropriate time to face and discuss the moral and ethical issues involved in the commercial harvesting of whales," says Robbins Barstow (1989:10; emphases added), director of Cetacean Society International. This is echoed by, among others, the U.S. commissioner to the IWC, John Knauss, who in an interview stated that he thereafter would have to oppose whaling on ethical grounds since scientific evidence now indicates that some stocks can be hunted under proper protective measures (Marine Mammal News, 1991). Scheffer (1991), a former member of the U.S. Marine Mammal Commission, has tried (partly tautologically) to give four reasons why we should care about whales: because whales figure as icons or totems in the animal liberation movement; because they are marvellous and mysterious; because they are beautiful; and because they enrich our folklore.

Although such sentiments are by no means new to the environmental movement and have been particularly strong in Greenpeace (Herscovici, 1985; Brown and May, 1989; Pearse, 
1991), organizations that hitherto have claimed to be concerned solely with ecological issues have also come to question the ethics of harvesting whales. World Wide Fund for Nature (alias World Wildlife Fund, WWF), for example, stated in a press release before the opening of the 43rd annual meeting of the IWC in Reykjavik in 1991 that "as more and more people worldwide become aware of the remarkable qualities of whales, there is increasing doubt about the ethics of killing whales for commercial profit even if it could be guaranteed to be both sustainable and humane." WWF leaders have repeatedly argued that commercial whaling is unethical. In a letter dated 23 January 1992 to the Swedish ministers of environment and agriculture, for example, the general-secretary of WWF-Sweden, Jens Wahlstedt, stressed that whales have such great symbolic value that a resumption of commercial whaling is unacceptable.

There can be little doubt that influential leaders within the WWF and Greenpeace have placed themselves among the animal rights advocates. In so doing, they blur a distinction that should prevail between two concepts. Environmentalists are concerned about environments as ecological systems and therefore work to secure habitat and species diversity. A species' survival is, of course, an ecological issue, but not so the well-being of individual animals (Lynge, 1990:47). The latter is the concern of animal rights advocates who are against killing of animals per se. But unlike the mainstream animal rights proponents, most of the anti-whalers have few misgivings as to lethal consumption of domesticated animals, such as calves, pigs, lambs, turkeys, and chickens. To them whales are unique.

It has been argued that there is a growing tendency in modern society to treat certain animals as totems (Menninger, 1951), which might be caused by modern man's need to compensate for being alienated from nature or, as Menninger points out, by a person's inability to satisfy social and emotional, including sexual, cravings in company with fellow human beings. My objective is, however, not to analyze the psychological needs behind our totems, but rather to analyze why some animals e.g., whales - make better totems than others for many environmentalists and animal rights advocates. How are whales turned into a powerful symbol - a "super-whale," which in several ways resembles a totem - and why have whales such great potential as a symbol to an ever-increasing number of people, particularly in Western urban societies? What is unique about whales? A second objective is to explore the implications of turning whales into totems. More precisely, the paper will explore how, in the zeal to protect this totem animal against all lethal "consumptive use," whalers and eaters of whale meat are being depicted as savages or reckless capitalists, thus dichotomizing mankind into "good" people (whale lovers) and "bad" people (whalers, whale eaters). Or to put the causality the other way around: how, by totemizing the prey of whalers, the whale protectionists can construct an image of themselves as caring and peaceful by portraying the whalers as greedy and barbarous. Finally, a case study from northern Norway will throw light on the social and cultural costs inflicted upon local communities by managing natural resources through totemization.

\section{THE CREATION OF A "SUPER-WHALE"}

Whales are, according to Barstow (1991), special in five different ways: biologically, ecologically, culturally, politically, and symbolically.

\section{Biologically Special}

First, says Barstow, the whales are biologically special. The blue whale is the largest animal on earth, which is of course true, but the cetacean family also includes the small common porpoise, which measures less than $2 \mathrm{~m}$. Barstow continues by stating that the sperm whale has "by far the largest brain of any creature ever to have lived on our planet" (1991:6) but fails to say that the brain is only slightly bigger than that of an Asiatic elephant and constitutes only $0.021 \%$ of the animal's body weight, as compared to $0.08 \%$ for a cow, $0.15 \%$ for the elephant, and $2.1 \%$ for human beings (Freeman, 1990:112). Then he postulates that several species have more complex brains than human beings. Others have carried this argument further, such as the former leader of Greenpeace's anti-whaling campaign, Mikael Gylling-Nielsen, who in an article entitled "Havets mennesker" ("The humans of the oceans") claims that "it is generally accepted that the structures of dolphin and human brains, including size, the number and area of convolutions of the brain, and cellular organization, are identical" (GyllingNielsen, 1987:11).

The cetaceans' apparent ability to communicate is also taken as an indication of their intelligence. The humpback whale's rich repertoire of sounds inspired Heathcote Williams to write the following poem about whale songs and oral traditions allegedly going back 50 million years (Williams, 1988:17):

Webs of elegant cetacean music stretch around the globe;

Lyrical litanies on the bio-radio

That draw on an oral tradition of submarine songs

From a living memory bank, founded fifty million years ago.

Another aspect that fascinates many is the ability of at least some species for echo-location and scanning by ultrasonic waves. Here some authors' imaginations appear to have no limits. "When we human beings say that we feel fine although in fact we do not," writes Johannsen (1990:45) in his book Hvalernes verden, published in cooperation with WWF-Denmark, "the dolphins can perhaps see, or rather hear, whether another dolphin is really ill or healthy." Abbey (1990:41) writes in similar vein in his novel The Last Whales. When a group of dolphins surrounded a male blue whale who was not feeling healthy, one of them scanned the whale and diagnosed it as having worms in its kidneys.

Frequently claims for the high intelligence of whales are wrapped in a mystical language rendering the meaning almost incomprehensible. Quoting Lilly's (1967) pioneering work in man-dolphin communication, D'Amato and Chopra (1991:21-22) have argued for "whale rights" based on the whale's unique intelligence:

If a sperm whale, for example, wants to see-hear-feel any past experience, his huge computer [brain] can reprogram it and run it off again. His huge computer gives him a reliving, as if with a three-dimensional sound-color-taste-emotion re-experiencing motion picture.

This led D'Amato and Chopra (1991:21) to claim that there is no need for writers of science fiction to speculate about higher than human intelligence in outer space, since there might already exist such forms of life on earth, e.g., the whales. By taking Lilly as their source and ignoring all scientists of a different opinion, D'Amato and Chopra forget that this presumed high intelligence of whales is sheer speculation rather than established fact. 
It is by no means generally accepted that the dolphin and human brains are identical, however. On the contrary, many scientists have questioned the great intelligence of dolphins (Prescott, 1981; Pryor, 1981), while others have argued that dolphin brains are more similar to brains of hoofed animals (Bryden and Cockeron, 1989:161). Klinowska (1988:46), who is a special adviser to the World Conservation Union (IUCN), concludes that the dolphin's brain has hardly evolved since the cetaceans left land for a life in the oceans and has been stuck at the paralimbic-parinsular stage, which is the most primitive stage in land mammals. Thus dolphin brains are in structure more similar to those of hedgehogs and bats than those of primates.

The whales' ability to communicate, moreover, does not necessarily imply high intelligence, as the rich repertoire of signals among the honey bees testifies. The echo-location is obviously a device cetaceans use to navigate under water and is a part of their genetic heritage, as it is among bats. That "the whales invented ultrasonic scanning" (italics added) millions of years before we started to use the technology in our hospitals, as claimed by Johannsen (1990:45), falls on its own absurdity.

\section{Ecologically Special}

Barstow (1991:6) is also of the opinion that whales are ecologically special. It is stressed that whales probably are at least 25 million years old (1991:6), but other animals have existed even longer without being the object of the same veneration. Furthermore, Barstow claims that whales are at the top of the food chain. The baleen whales are the largest eaters of zooplankton and the killer whale is the largest non-human predator. This is hardly controversial, nor is the claim that we all depend on oxygen in the atmosphere. But his assertion that "the proper balance in the amount of oxygen in the earth's atmosphere produced from the plankton . . . is kept in check most critically by whale consumption" (Barstow, 1989:13) is not substantiated in any way.

The leap from this kind of "ecological" argument to the following letter written by a British woman to the Faroese government is not that great (quoted in full in Sanderson, 1990:199):

The Slaughter in the Faroes of the dolphins and whales is causing untold damage to the ozone layer. The special sound the dolphins and whales emit holds the ozone layer together. It is the utmost importance to stop this terrible slaughtering of these wonderful creatures, so many of which are far more evolved than man.

PS: The dolphins are the guardians of this planet.

Every species has a special role to play in the ecosystem, Homo sapiens included. In a way we are all unique. At the same time it is difficult, and dangerous, to argue that certain mammals are ecologically more important than others. On what criteria should we base such a ranking among living species?

Many people believe that whales are endangered. But that most marine mammal stocks are abundant and only a few of the more than 75 species of cetaceans are endangered (Aron, 1988 ) is concealed by whale protectionists. That the minke whale - which Greenland, Iceland, Japan, and Norway want to harvest - is not endangered and might be more abundant in the Antarctic than ever (Gulland, 1988:44) is not mentioned. Nor is the fact that there are, according to American estimates (Aron, 1988:104), about 2 million sperm whales even though they are on the list of "endangered species." That a few species, such as the blue and bowhead whales, are endangered does not justify a total moratorium on all killing of all whales. After all, the fact that the white-tailed eagle seems to be endangered does not mean that we should protect all birds, chickens included. When WWF-Denmark ran its "SOS Save the Whale" campaign, its leaders must have been fully aware that the organization deceived large groups of people in an effort to increase its income. Barstow is more honest when he confesses that scientific data show that "at least some species of whales could easily sustain a resumed, strictly-regulated harvest, without threatening species survival" (Barstow, 1989:10). It is this fact that has forced him to take up moral and ethical issues involved in the commercial harvesting of whales.

\section{Culturally, Politically, and Symbolically Special}

To Barstow whales are culturally unique, not only because whales, like the "friendly" gray whales, allegedly have a greater capacity than any other animal to enrich our lives through peaceful contact, but also because "they are supremely photogenic," they have special aesthetic qualities, and they play an important role in education. Moreover, whales appear to carry no grudges against men despite the centuries of their being victimized by human predation (Barstow, 1991:6).

Whales have made a great impact in popular culture, and the value of "non-consumptive use" of cetaceans today far exceeds the value of whaling (Kalland, 1992). A number of books, magazines, television and radio broadcastings, motion pictures, records, paintings and other art objects, whale-watching tours, dolphinariums, and computer games cater to the consumers. Dolphins, in particular, stir people's imaginations and have become popular in science fiction literature, for example.

Politically the whales are regarded as special because they do not know national borders, which is one reason why it is claimed that whales must be managed by international bodies. But this is not unique to whales and is equally valid to some fish and birds, which may travel much longer distances than toothed whales, which, with the exception of adult sperm whales, usually do not migrate widely (Watson, 1985:51).

If whales are culturally and politically unique, this is so not because of some unique qualities in whales per se, but as a result of how we perceive whales. In other words, the perceived cultural and political uniqueness of whales is an effect of human activities and thus a cultural product, created mainly by urban people in the Western world under certain economic and political conditions. What is culturally and politically unique about whales is no more than an invention of the human - or certain humans' - mind. The same can be said about the symbolic uniqueness of whales. When Barstow points out that whales have come to symbolize concern for all life in this "water planet" (1991:7), this fact tells us more about human society and culture than about whales.

In summary, we are told that the whale is the largest animal on earth (this applies to the blue whale), that the whale has the largest brain on earth (the sperm whale), that the whale has a large brain to body weight ratio (the bottlenose dolphin), that the whale has a pleasant and varied song (the humpback), that the whale is friendly (the gray whale), that the whale is endangered (the bowhead and blue whales), and so on. By talking about the whale, an image of a single whale possessing all of these traits emerges. But such a creature does not exist. It is a mythic creation - a "super-whale," which has come to represent all species of cetaceans. 


\section{WHY WHALES?}

Why do so many people and organizations spend so much time and energy on creating this image, and why does this image of the super-whale have such an appeal and sell so well? Why are marine mammals offered better protection by U.S. laws than any other species (Manning, 1989:220)? There are a number of answers to these questions, ranging from economy and politics to information management and psychology.

In the first place, there are pragmatic reasons to jump on the anti-whaling - and anti-sealing - bandwagon. Of course, environmentalists as well as animal rights activists have learned that whales and seals open people's purses, and they skillfully play up to this tendency ( $c f$. the fake photograph of Brigitte Bardot with a seal pup). Successes attract people to the cause, and the odds of winning are important considerations when selecting issues - not only because of the money this gives the organizations, but also because a large number of members and supporters makes the organizations more able to function as strong pressure groups. Harald Zindler, a Greenpeace leader in Germany, called themselves "strategische Opportunisten" (Schwarz, 1991:105), while Steve Sawyer, international director of Greenpeace, has stated that the philosophy of the organization is very pragmatic: the leaders choose issues they feel they are able to win (Pearse, 1991:40). Victories are given top priority (Eyerman and Jamison, 1989:104), since victories, particularly if they are won against apparently great odds, bring money and supporters. Hence, the organizations tend to exaggerate crises and the strength of their adversaries. The organizations typically urge sympathizers to donate more money before the annual IWC meetings, when they give the impression that the present moratorium is in danger of being lifted.

The whaling issue is also an ideal issue for national governments and polluting industries to support. Whaling being of only marginal economic importance - and in most countries of no importance at all - this is a "safe" issue and there is hardly anything to lose by joining the crowd. The rewards in terms of "green images" are, on the other hand, substantial (Rose, 1989). The anti-whaling campaign, therefore, offers governments and industries an opportunity to show their consideration for the environment, while the campaign has proved an excellent fund raiser for the environmental and animal rights movements. Gulland (1988:45), an adviser to the IWC, has pointed out that "There may no longer be urgent reasons of conservation for continued pressure to strengthen the control of whaling, but there are sound financial reasons for groups that depend on public subscription to be seen to be active in 'saving the whale." "To summarize, the anti-whaling campaign attracts organizations for the same reasons as the anti-sealing campaign, i.e., the potential supporters are relatively isolated from the negative effects of the campaign and the goal of the campaign appears to be relatively inexpensive (Allen, 1979:424).

The question remains, however, why people attach so much importance to whales and therefore more readily donate money in order to "save" them rather than endangered bats, for example. Although preferential attitudes, which are said to exist toward large (Kellert, 1988) and juvenile-looking animals (Lorentz, 1981) in modern society, may help turn large whales and seal pups into likely candidates for totemic treatment, there are undoubtedly other factors working in the same direction.

\section{The Symbolic Power of Whales and Salt Water}

First, whales are animals to which symbolic significance can easily be ascribed. In the way in which we categorize the world around us, mammals usually have four legs and walk on land. But whales - and seals - live in the sea and not on land, and they have fins and not legs. Unlike fish, their tails are horizontal, rather than vertical, and they have no scales. Whales form an anomalous category of animals (Kalland and Moeran, 1992:5-6), since they do not fit into our simple categories of mammals and fish. Whales are "betwixt and between," and it is, according to Douglas (1966), exactly those animals difficult to fit into our cognitive maps that become the object of myths and taboos.

On the other hand, mythical creatures, such as mermaids, trolls, and ninja turtles, also fall in this "betwixt and between" category, because by definition they have traits found in various species. Our mythical super-whale is even more "betwixt and between" than its real cousin, in that animal rights people have cleverly created an image of an animal that is large and smart and fond of music and friendly and caring and so on ad infinitum. The less we know about real whales, the more can be left to our imagination, and the more "betwixt and between" the super-whale can be made.

Second, whales - and seals - move in salt water. We know very little about what is going on in the oceans, which turns the sea into a good "issue" on which to focus (Kalland and Moeran, 1992:7-8). Moreover, both salt and water are important purifying agents and are used in religious rites throughout the world. The ocean becomes the ultimate symbol of purity, of untouched nature, and thus stands in sharp contrast to the polluted soil on which we land mammals tread. It is we, who move on land, who pollute the pure sea. No wonder that when the Danish chemical company Brøste "bought" a sperm whale from the WWF in order to improve its green image - or perhaps to expiate previous sins - the whale was called "Brфste's pioneer whale loves pure salt water" (Brфstes pionerhval elsker rent saltvand).

But salt water has other qualities, of course. We all started our lives in the uterus submerged in this kind of water, and salty water is thus indispensable for our own existence. It has been suggested that people's attitudes to whales and seals are reflections of an unconscious memory of, and yearning for, life in the mother's womb (Grof, 1985:142; Lynge, 1990:60). But despite having lived our first months in water, we are unable to swim like a whale. Without technological aids such as diving gear and submarines, we are confined to life on land. Human beings may harbour a feeling of envy toward whales, as there is a feeling of envy toward birds for being able to move freely in the skies.

The humpback whales, and to a certain extent some of the dolphins, bridge the realms of sea and air, thus making them doubly fascinating. The humpback is able to jump out of water, waving its long flippers like wings. Greenpeace's inflatable humpback has been flown in anti-whaling demonstrations around the world, while countless humpback whales fly through the air in Japanese advertisements, often carrying children on their backs. The flying whale is also a topic in Williams's poems, and in one he links the unrestricted lives of whales, birds, and humans in the womb, thus giving credence to the claim that we yearn for life in the mother's womb (Williams, 1988:12):

Whales play, in an amniotic paradise.

Their light minds shaped by buoyancy, unrestricted by gravity,

Somersaulting,

Like angels, or birds;

Like our own lives, in the womb. 


\section{Since Ancient Times}

Third, as many of the protectionists never fail to point out, the cetacean brain developed long before the development of human beings (Barstow, 1991:6) or, to use the words of Watson, a member of Seychelle's delegation to the IWC and a writer of para-psychology: "When men were insignificant nocturnal insectivores" (Watson, 1985:48).

With this long time perspective in mind, Lilly (quoted in Linehan, 1979:539) wants to find out whether dolphins have sagas and tell each other stories. Although it will, according to Lilly, take a lot of work before we can understand their stories, such trouble might well be justified if it is true - as Lilly wants us to believe - that dolphins administer knowledge that has been accumulated through an oral tradition more than 25 million years old. Such communication must be particularly rewarding for geologists, palaeontologists, and historians who here might have a large potential store of knowledge.

With this capacity for storytelling, it is no surprise to find that dolphins are supposed to have a rich and ancient culture and that they "represent the closest approach to civilization, not as defined in terms of machine or technology, but as realized among all intelligent beings, cetacean or human, where communication and social bonds transcended the mere exigencies of life" (Abbey, 1990:80). Composing and playing music are also cultural activities, and Johannsen (1990:83) claims that "the humpbacks have certainly composed for millenia, before the first stone age man even got the idea of beating two bones in rhythm."

One may wonder why it is so important to stress that whales have lived on this planet for millions of years. Although Klinowska (1988:46) has pointed out that cetacean brains have hardly developed since the animals left shore for a life in the oceans, many whale protectionists argue that cetaceans have had more time than man to evolve into intelligent creatures. While some authors are satisfied by claiming a 25 - to 30 -million-year history for whales, others write 50 (Williams, 1988:17) or even 70 million years (WWF-Denmark, 1990). The antiquity of cetaceans seems to place whales above humans. They are more advanced than we are, they are our teachers and may have more to teach us than we have to teach them (Lilly, 1961, quoted in Williams, 1988:113).

The long history of whales also seems to give them some unique rights to the oceans. Barstow (1991:6) writes that human beings have intruded into the territory of whales. The whales thus emerge as the "aborigines" of the sea, leading ultimately to the premise of closing the oceans for many human activities in the same way as aboriginal lands are being closed to certain activities of white people.

\section{Lost Paradise}

While the whales have lived in peaceful co-existence with their surroundings for 25 million years or more - or so whale protectionists would have us believe - human beings have played havoc on the earth and have lost their paradise after only a fraction of that time. Rapid urbanization has been seen as leading to alienation and loss of purpose in life, to collapse of social networks, to soaring crime and divorce rates, and to the young increasingly turning to drugs. Our social skills have been undermined. In much of the argument about the peculiarities of whales we are presented precisely with the qualities that urban men and women seem to have lost. Or perhaps we never had these skills in the first place, because, according to Watson (1985:48), "our best-developed areas are those which deal with the elaboration of motor skills made possible by our hands, while cetaceans seem to concentrate on areas of social perception. Dolphins show marked development of those parts of the brain responsible for orientation, social skill, emotional self-control and perhaps even humour."

Closely related to this is the question of caring for each other. While commercialization has penetrated most human relations, whales are depicted as the guardians of old values. The whales allegedly care for the sick and dying, while people in the urbanized Western world pay hospitals and old people's homes to take care of aging relatives, thus removing the sick and dying from sight. Ours is a death-denying society (Lawrence, 1986:53). Moreover, the super-whales take care of each other's calves. They babysit and run nurseries (Watson, 1985:41), without charging anything for these services. Not only do they care for their own kind, time and time again tales of whales rescuing humans are told. Men and women might also have behaved nobly, but that was in the past. Today money rules, and urbanites carry with them a nagging bad conscience, a bad conscience for not taking care of aging parents and for not giving children the attention they need.

Whether we have lost our social skills through rapid social change, or whether we have never been very clever at handling social relations, as implied by Watson $(1985: 48)$, the message is the same: we are in these respects inferior to whales. Whales are endowed with all the qualities we would like to see in our fellow men - kind, caring, playful. We have something to learn, and whales are therefore used for didactic purposes, just as "good" birds have been used to give children bourgeois values (Löfgren, 1985). The whales, and "nice" birds, have become models for us to emulate, and people do not eat their teachers and models, at least not in the Western urban world. Whale meat has to become taboo, and eating it becomes a barbarous act close to cannibalism. Whales are taking on the characteristics of a totem.

\section{THE WHALE AS TOTEM}

Levi-Strauss (1966:37) has pointed out that "The beings which native thought endows with significance are seen as exhibiting a certain affinity with man." The super-whale has this affinity with men. It is our counterpart in the sea; it is the "human of the oceans." It has qualities we would like to see in humans. In fact, according to Barstow (1989:13), whales have a unique affinity for human beings. They love us and like to entertain us, thus enriching our lives, but allegedly we can also enrich theirs (Barstow, 1991:7).

Discussing the relationship between man and his totem animal, Durkheim (1976:139) makes the important point that this relationship is not that of a believer towards his god, but rather one between two beings on the same level, between equals. The whales are claimed to be our equal, if not our superior. They mate "face to face, like man" (Williams, 1988:41), and whale songs are carried together with those of humans on Voyager I and II through space. We are told that whales are at least as intelligent as we are, they are more skilled in handling social relations, they deserve "whale rights," and there are talks about "whalekind" as a counterpart to mankind. But the whale, or rather the super-whale, has taken on other characteristics of the totem as well. 
Often, but not always, a group of people regard their totem as their ancestor. Few people claim that the whales are our ancestors, but by stressing the antiquity of whales and by claiming that whales might be placed on a higher level than Homo sapiens on the evolutionary pyramid (by being a more ancient species, more intelligent, more apt at handling social affairs, etc.), it can be argued that they have come to play the role of pseudo-ancestors. Moreover, a totem is frequently regarded as "the guardian spirit and helper" (Freud, 1960:2), and the many stories of whales, particularly dolphins, rescuing people at sea clearly testify to this ability among cetaceans. It is also claimed that swimming with dolphins is a therapy for handicapped children and for people suffering from depression (Dobbs, 1990; Hatt, 1990).

In return for their services, people come "under a sacred obligation . . . not to kill or destroy their totem and avoid eating its flesh" (Freud, 1960:2). Although this prohibition is not absolute or universal in totemism (Durkheim, 1976), protecting the whales has become the most sacred duty of many people, as became clear to the whole world when three gray whales were trapped in the ice off Barrow, Alaska, in 1988 (Rose, 1989). But, unlike in traditional totemic societies - as found among the aborigines in Australia and Indians in North America, where prohibitions extend only to the group with that particular totem - and unlike the Hindus, who in no way try to impose the prohibitions of killing and eating cows on the rest of mankind, whale protectionists try to make the prohibition universal. In their zeal they continue a form of Western cultural imperialism initiated by Christian missionaries. This merger of totemism and cultural imperialism has turned whaling into a national symbol in some of the protectionists' target societies (Brydon, 1990; Kalland and Moeran, 1992:193-195; ISG, 1992:114-115).

Finally, the totem plays a leading role in the ritual life of its human fellows. Most spectacular are the much publicized actions against whalers and sealers. They are usually carefully staged and the mass media play a crucial role in transmitting a rather theatrical performance across the world. Although a nuisance to whalers and sealers, these actions are not meant to bring forth an immediate termination of hunting activities. What these rituals do is invent news (Hunter, 1979:178) that tells the world that the activists are concerned about the environment, that the issue is urgent and cannot wait, and that they fight against great odds. The activists are depicted as underdogs; it is the small zodiac against the big catching boat, or swimming Greenpeacers in front of a Japanese factory ship. It raises enormous sympathy for their cause. But the picture is false. Environmentalism is a multi-billion-dollar industry, and as long as the issues are whales and seals - and perhaps dogs and cats - they secure official backing from the Anglo-Saxon world. It is rather the whalers and the sealers who are the weak party.

Once a year whale protectionists gather at the annual meetings of the IWC, where the world is divided into the so-called "like-minded group" and the "whaling nations." Here activists can display their whale art objects and emblems (a typical totemic trait, Durkheim, 1976, especially p.13-119) on badges, T-shirts, posters, and so on. Although the outcome of the meetings in recent years has been more or less known, the meetings themselves give those concerned the opportunity to meet like-minded politicians, activists, and journalists.
Moreover, the IWC meetings make it possible to bring the whaling issue to the news headlines once a year.

There is also whale-watching tourism, which has grown into a multi-million-dollar industry and which opens the whale rituals to a larger audience than spectacular actions at sea or IWC meetings can do. Here affluent people can observe whales firsthand. Not only can they "save" whales, but they can "meet" them, "engage" them, and even "touch" them. For them, as for the writer of the history of Greenpeace, there can be a "transcendent element lying at the center of the undertaking." They, too, can be said to be in search of their "Holy Grail" (Hunter, 1979:150).

\section{Bad Guys and Good Guys}

Through these rituals "like-minded people" are brought together, and solidarity and group identity are maintained and strengthened. But totemism and its accompanying rituals are more than a means to integrate groups of people. Totemism is a taxonomy where nature is used to classify people and thus implies opposition between groups of people. In the words of Levi-Strauss (1966:115): "The homology [the totemic institutions] evoke is not between social groups and natural objects but between the differences which manifest themselves on the level of groups on the one hand and that of species on the other."

Whales make better totems for the environmental and animal rights groups than, say, endangered bats and hedgehogs, because the whaling issue makes it easy to isolate a small group of culprits - e.g., the whalers - and confrontations can be focused narrowly on short hunts and annual meetings at the IWC. For the same reasons hunting of not-endangered harp seals during a short season off northeastern Canada makes a better case, and the harp seal a better totem, than slow extermination of the highly endangered Mediterranean monk seal due to pollution, tourism, and military activities (Johnson, 1988).

A totemic system requires at least two opposing groups, each with a totem. What then is the whalers' totem? Since whales for the protectionists function metonymically for nature as a whole, it follows that the totem of the whalers must be some man-made object. Money serves this function ideally because money can be used metaphorically for commercialism and the values we have lost, but which whales are claimed still to possess. A picture of a greedy whaler maximizing money is therefore promoted in the protectors' rhetoric. Whalers are depicted as "butchers willing to wipe out the world's last whales for profit" (Today, 28 May 1991). The task of portraying whalers in this way has been made easier by the memory of bygone days when large pelagic fleets hunted some large cetaceans almost to extinction in the search for whale oil. That coastal minke whaling in Iceland, Japan, and Norway has very little in common with the old pelagic whaling but, on the contrary, shares many of the characteristics found in aboriginal subsistence whaling (ISGSTW, 1992) does not seem to affect their rhetoric the least. Promoting money as the totem of whalers may also explain why commercial whaling is regarded as unethical, while several groups are ready to accept aboriginal subsistence whaling as long as they do not sell anything and use primitive methods (i.e., are close to nature).

The world has thus been divided between good guys and bad guys, the good guys being the "like-minded people" who fight to save their peaceful whale friends against the bad guys who 
want to kill for greed. A set of binary oppositions emerges in the worldview of many whale protectionists, which is, however, not shared by the whalers:

protectionists : whalers :: whales : money :: nature : man-made objects :: subsistence : commercialism :: tradition : modern :: good : bad

A few examples of the rhetoric used in creating this dichotomy, which apparently also seems to fit the sealing issue (Wenzel, 1991), are in order here. On the one side, the protectionists are typically depicted as good people. In a Christmas fund-raising letter, Brian D. Davies, the founder and executive director of International Fund for Animal Welfare (IFAW), writes that "we're pressing for peace ... not pain. For care and compassion . . . not clubbing and killing. For kindness . . . instead of cruelty" (December 1991).

Like sealers (Wright, 1984:24, 102; Herscovici, 1985:73-76), whalers are frequently accused of using cruel and inhumane killing methods, and headlines like "Blood on the water," "Fresh call to kill," or "Whale killers defend their crime" are common. At the same time, the moral integrity of the whalers and their supporters is questioned. In addition to killing whales, they are also potentially violent towards fellow people, if we are to believe Gert S $\phi$ rensen, a Danish Greenpeace activist. On the pretext of being a scientist, he was welcomed onboard a Norwegian minke whaler, but he went ashore after a couple of days because he was afraid that the whalers might stab him with knives if his identity were revealed (Claudi, 1988:91).

D'Amato and Chopra (1991:27) suggest that "The mind set that exults in the killing of whales and the 'sports' hunting of endangered wildlife species overlaps with the mind set that accepts genocide of 'inferior' human beings." This is echoed by World Society for the Protection of Animals, which in a circular (No. 881406) claims that children exposed to hunting activities are more likely later to show violent criminal behaviour towards people. If this is true one may wonder why the crime rates in traditional hunting societies in general are low compared to those in U.S. cities.

Whalers are often portrayed as less civilized than the "likeminded group." The more sober British newspaper, The Times, writes in an editorial - after first pointing out that minke whales are plentiful, a fact that has forced the British Minister of Agriculture, John Gummer, to change his argument from one of ecology to another of humane killing - that a "return to the cruelty of existing methods of whaling by Norway, Japan and Iceland will damage their reputation as civilised societies" (29 May 1991). In a letter to the Washington-based ambassadors of the whaling nations (dated 25 May 1991) the president of WWF, Kathryn S. Fuller, urges the whaling nations to terminate whaling and thereby join the world community. Some people see a process of evolution from the primitive and barbaric to the civilized. To animal rights advocates there is an ethical progression through which we first liberate ourselves from the yokes of racism, then of sexism, and finally of speciesism, e.g., discrimination on the basis of species (Singer, 1990:9). Attitudes to whales and whaling are frequently used to measure this progress. In Barstow's (1989:11) evolutionary scheme mankind has progressed from cannibalism and emancipation of slaves to liberation of whales. And for D'Amato and Chopra (1991:49) caring for whales signals a progression from self-interest to altruism, or from individualism to communalism. Scheffer (1991:19) sums it up by claiming that caring about whales is a mark of personal and societal maturity.
If whaling is barbaric, eating whale meat is no less barbaric. Tabloid newspapers, for example, print extremist headlines, such as "Greedy Japs gorge on a mountain of whale meat at sick feast" in a "banquet of blood" (Daily Star, 11 May 1991), that turn the consumption of whale meat into sensational events that underline pre-existing myths. For those who have a tradition of eating whale meat, these accusations are both humiliating and seen as cultural imperialism.

\section{IMPLICATIONS}

The strategy of totemizing the whales has proved effective in protecting whale stocks from exploitation. And costs are minimal to the environmental and animal rights groups in that the anti-whaling campaign attacks people residing in marginal regions in the North, largely unable to fight back, as does the anti-sealing campaign (Herscovici, 1985; Wenzel, 1991). That there are few whaling nations makes these nations ideal scapegoats.

The question remains, however, whether totemization is an optimal way of managing resources. There are reasons to believe that a total moratorium on hunting sea mammals will seriously harm the ecosystem, since toothed whales feed on fish and molluscs and baleen whales seem to do so to an extent not hitherto realized ( $c f$. M $\varnothing$ nnesland et al., 1990). If certain types of whales were to become too numerous, their food supplies would dwindle and they could literally starve to death (Terhune, 1985; Aron, 1988), unless a moratorium is also imposed on fishing. One step in that direction was taken when Greenpeace in June 1991 sued the National Marine Fisheries Service (NMFS) for giving an additional 30000 tons of pollock to the Gulf of Alaska trawl fleet, fish which, according to Greenpeace, rightly belonged to the sea lions (National Fisherman, September 1991:8).

The possible consequences of such a policy should be obvious. Although scientists disagree as to the significance of growing sea mammal populations on fisheries, there are several indications that sea mammals and humans compete for marine resources (Manning, 1989:226-228). To place a taboo on catching sea mammals will thus not only remove these species from the fishermen's niche, but might have the added effect of reducing, and in some extreme cases eliminating, other marine resources as well. This may have particularly severe consequences in the Arctic, where the ecosystem is characterized by the occurrence of relatively few, but at times abundant, species and where marine mammals occupy a large proportion of the total biomass (Freeman, 1984).

\section{Implications for Northern Norway}

The situation in northern Norway, where minke whaling has been an integral part of the coastal fisheries since about 1930 (ISG, 1992), resembles that found elsewhere in the Arctic, where people have relied on multispecies niches to compensate for great seasonal and annual fluctuations in their resource base. Whaling, which was conducted during the few short summer months, fitted into an annual cycle in combination with herring (or capelin) and cod fisheries, supplemented by subsistence farming and collecting of eggs and down (ISG, 1992). The "fisher-farmer" was the norm, with women doing much of the farm work, besides working in the processing plants and taking care of financial and administrative matters relating to their 
husbands' boats as "ground crews" (Gerrard, 1983). Whaling was a household enterprise, and when the moratorium was imposed in 1987, the typical whaling vessel of 60-70 feet was owner operated and carried a crew of 4-7 persons, many of whom were close relatives of the owner-skipper. In many respects Norwegian small-type whaling can be characterized as "simple commodity production" and falls within the category "artisanal fishery" (ISGSTW, 1992).

Since the end of World War II the policies formulated by the central authorities located in Oslo have worked to separate the fisherman from the farmer in the name of efficiency (Brox, 1966). New restrictions on fisheries have forced the fishermen to specialize further. Bringing the number of licences to catch minke whales down from 378 in 1949 to 53 in 1987 was one device in this process of specialization. By having small whales removed from their niche, the fishermen are brought still closer to single-species niches, or "mono-cropping."

It is difficult for the whalers to compensate their loss of income from whaling (which often amounted to $50-70 \%$ of their annual income) by increasing their efforts in other fisheries for which they are licensed, because most fisheries are already heavily over-capitalized and regulated by quotas. To diversify and take up new fisheries is not an easy solution either. Presently it is very difficult to obtain new licences. Moreover, most of the whalers do not have the financial means to invest in new gear - which incidentally will only add to the problem of over-capitalization - and it takes time to learn the skills required to handle new, sophisticated fishing equipment. Consequently, most whalers have been unable to form viable units with the resources left to them and have lately hardly covered maintenance expenses on their boats (Mønnesland et al., 1990:52). Many have been reduced to becoming recipients of social welfare in the form of minstelott, by which fishermen are guaranteed a minimum income by the state. Several whalers have lost their boats to creditors and some are in danger of losing their houses. Moving to urban centres or taking employment on industrial fishing vessels are the most likely options for many.

With minke whales being removed from the niche, the Norwegian fishing industry is further capitalized and specialized. But specialization reduces the fishermen's ability to adjust to ecological changes and ecosystem fluctuations in the future. The cessation of whaling will also have a negative impact on the remaining fishing fleet, as fishing communities seem to depend on a certain minimum size in order to be viable (Jentoft, 1991). Fishermen are not only competitors in a zero-sum game, but they also cooperate, share information, and support each other in various other ways.

Many of the small fishing villages along the barren coasts of northern Norway are facing rapid depopulation. In the municipality of Moskenes, located in the Lofoten archipelago, for example, migration has reduced the population from about 2000 to 1500 during the last 20 years, and an estimated $24-26 \%$ is de facto unemployed during the summer months, which was the season when the seven whaling boats registered in the municipality used to go whaling (ISG, 1992:59).

People are moving out for many reasons, but the moratorium is one contributing factor, both because of the immediate loss of income to the whalers and their families and because of the uncertainties the fishermen feel for the future. With resources within their niches being totemized, they feel that they are losing to international institutions and pressure groups what little there was left of their influence on management of the natural resources on which their livelihood depends. Moreover, their way of life has been ridiculed by certain groups. The moratorium as well as the environmental and animal rights movements have come to symbolize their loss of influence and pride. A pessimistic mood is noticeable in many communities, whose members feel left to the mercy of outsiders, and more people might be inclined to give up and move to the cities in the future. The whalers are quick to point out this paradox of the activities of what the whalers like to term "the so-called environmentalists," as much of the anti-whaling movement is known to be anti-capitalistic in nature and preaches sustainable development and a small-is-beautiful philosophy.

It might seem a paradox that there exists a conflict between environmentalists and people making a living from marine resources. Nobody depends more on a healthy environment than fishermen and hunters, and they are the first to see the need for protecting natural resources against depletion. However, more often than not, fishermen in Norway also feel that many of the restrictions imposed on their activities are ill founded and more an outcome of political than ecologic considerations. Frequently they feel that the decisions are made "over their heads" and that they gradually have lost influence on their own future. It is common for fishermen to tend to ignore, or evade, regulations they do not understand, and regional management and fishermen's co-management have been seen as a possible remedy (Pinkerton, 1989). Stronger local participation in management has also been urged in the report Caring for the Earth: A Strategy for Sustainable Living, jointly published by IUCN, UNEP, and WWF (1991:16). Yet, when it comes to the management of whales the current trend goes in the opposite direction. The report simply states that "the moratorium on commercial whaling should be maintained" (1991:158), without giving any reasons. And anti-whalers try to place the management of all cetaceans, including relatively stationary small dolphins and porpoises, under one international body, the IWC. The Norwegian whalers are bewildered and have turned against the environmental movements in general, making it difficult for the more moderate local groups to be taken seriously. Whales have in Norway, like seals in Iceland (Einarsson, 1990:40), become metaphors of environmental and animal welfare groups, not only for these groups. Moreover, the campaign against whaling has turned the eating of whale meat into a symbol of resistance. If whalers cannot defeat these groups, they can at least eat their totem. Both the ritual eating of whale meat in Lofoten's main township Svolvær on 4 July 1991 and a slowly growing demand for seal meat can be understood as symbolic attacks on the protectionists. But turning whales and seals into symbols of the animal rights advocates will in the long run not be in the interest of the ecosystem.

\section{CONCLUSION}

Totemizing the whales has effectively eliminated commercial whaling even on species that could sustain a regulated harvest, but the wisdom of this strategy has been questioned. To fit their totemic world view, whale protectionists have classified smalltype whaling (defined in the Definition Section C of the IWC's Schedule as hunting of minke, pilot, bottlenose, killer, and beaked whales by powered vessels with mounted harpoon guns) with industrial whaling because most of the meat is sold for cash and not bartered. They ignore that minke whaling shares many characteristics with aboriginal subsistence whaling for the 
following reasons: minke whalers exploit a multi-resource niche where whales constitute only one of several marine and terrestrial resources; the relation of production is based on kinship and the household constitutes the unit for both production and consumption; and knowledge of whaling, including ritual knowledge, is transmitted within households or between closely related households (as between an uncle and his nephews). In short, people share strong community, familial, social, and cultural ties related to a continuing traditional dependence on whaling and the use of whales, which was the reason given by the IWC (1981:3) for allowing aboriginal whaling. Small-type whaling is a far cry from industrial whaling, with its "monocropping," capitalist relations of production, individual outlook, and bureaucratic recruitment procedures.

The moratorium has had serious implications economically, ecologically, socially, and culturally. Norwegian fishermen have been pushed further toward single-species niches and thus have become more vulnerable to ecological fluctuations. Due to lack of alternatives, they may be forced to harvest the few resources still available to them beyond the level of sustainability or leave fishing for a life in the cities. Being ridiculed as barbaric and feeling that they have lost the little influence they hitherto had on the management of the natural resources on which their livelihood depends further encourage them to move. Such a development is hardly in the interest of the environment.

\section{ACKNOWLEDGEMENTS}

During the last four years I have been fortunate to participate in several workshops and symposia on whaling, and I am particularly indebted to the participants of the international workshop on SmallType Coastal Whaling in Japan (held in Japan in April/May 1988), to the participants of the International Study Group on Norwegian Small Type Whaling that met in Norway in April 1991, and to the participants of the symposium on the Utilization of Marine Living Resources for Subsistence (held in Japan in January 1992). Among the many participants and others who have helped me in one way or another, I am especially grateful to Milton M.R. Freeman and Brian Moeran.

Fieldwork was conducted by the author in Norwegian whaling communities during summer 1990 and by the International Study Group on Norwegian Small Type Whaling in April 1991. The latter study was made possible by grants from the Regional Authorities of Northern Norway, the Norwegian Ministry of Fisheries, and the Norwegian Fishermen's Association.

\section{REFERENCES}

ABBEY, L. 1990. The last whales. London: Doubleday.

ALASKA CONSULTANTS INC., with STEPHEN BRAUND \& ASSOCIATES. 1984. Subsistence study of Alaska Eskimo whaling villages. Report to the U.S. Department of Interior, Washington, D.C.

ALLEN, J. 1979. Anti sealing as an industry. Journal of Political Economy 87(2):423-428.

ARON, W. 1988. The commons revisited: Thoughts on marine mammal management. Coastal Management 16(2):99-110.

BARSTOW, R. 1989. Beyond whale species survival: Peaceful coexistence and mutual enrichment as a basis for human/cetacean relations. Sonar 2:10-13. 1991. Whales are uniquely special. In: Davies, N., Smith, A.M., Whyte, S.R., and Williams, V., eds. Why whales? Bath: Whale and Dolphin Conservation Society.

BARTH, F. 1969. Ecological relationships of ethnic groups in Swat, North Pakistan. In: Vayda, A.P., ed. Environment and cultural behaviour Ecological studies in cultural anthropology. Austin: University of Texas Press. 362-376.

BROWN, M., and MAY, J. 1989. The Greenpeace story. London: Dorling Kindersley.
BROX, O. 1966. Hva skjer i Nord-Norge? Oslo: Pax.

BRYDEN, M.M., and COCKERON, P. 1989. Intelligence. In: Harrison, R., and Bryden, M.M., eds. Whales, dolphins and porpoises. New York: Fact on File Publication. 160-165.

BRYDON, A. 1990. Icelandic nationalism and the whaling issue. North Atlantic Studies 2(1-2):185-191.

CLAUDI, E. 1988. Greenpeace. Vol. 1. Regnbuens krigere. Copenhagen: Tiderne skifter.

D'AMATO, A., and CHOPRA, S.K. 1991. Whales: Their emerging right to life. American Journal of International Law 85(1):21-62.

DOBBS, H. 1990. Dance to a dolphin's song. London: Jonathan Cape.

DOUGLAS, M. 1966. Purity and danger: An analysis of the concepts of pollution and taboo. London: Routledge and Kegan Paul.

DURKHEIM, E. 1976. The elementary forms of the religious life. (Trans. from French by Joseph Ward Swain.) London: George Allen and Unwin.

EINARSSON, N. 1990. Of seals and souls: Changes in the position of seals in the world view of Icelandic small-scale fishermen. Maritime Anthropological Studies 3(2):35-48.

EYERMAN, R., and JAMISON, A. 1989. Environmental knowledge as an organizational weapon: The case of Greenpeace. Social Science Information 28:99-119.

FREEMAN, M. 1984. Arctic ecosystems. In: Engelhardt, F.R., ed. Handbook of the North American Indians. Vol. 5. Washington, D.C.: Smithsonian Institution. 36-48.

1990. A commentary on political issues with regard to contemporary whaling. North Atlantic Studies 2(1-2):106-116.

FREUD, S. 1960. Totem and taboo. London: Routledge and Kegan Paul.

GERRARD, S. 1983. Kvinner - fiskerinaringas bakkemannskap? In: Hersough, B., ed. Kan fiskerinæringa styres? Oslo: Novus Forlag.

GROF, S. 1985. Den indre rejse. Copenhagen: Borgens Forlag. Vol. 4. 142.

GULLAND, J. 1988. The end of whaling? New Scientist, 29 October:42-47.

GYLLING-NIELSEN, M. 1987. Havets mennesker. Greenpeace Magasinet No. 1.

HATT, J. 1990. Enigmatic smiles. Harpers \& Queen, December:244-252.

HERSCOVICI, A. 1985. Second nature - The animal-rights controversy. Toronto: CBC Enterprises.

HUNTER, R. 1979. Warriors of the Rainbow: A chronicle of the Greenpeace movement. New York: Rinehart and Winston.

ISG (INTERNATIONAL STUDY GROUP ON NORWEGIAN SMALL TYPE WHALING). 1992. Norwegian small type whaling in cultural perspectives. Troms $\phi$ : Norwegian College of Fisheries Science.

ISGSTW (INTERNATIONAL STUDY GROUP FOR SMALL-TYPE WHALING). 1992. Similarities and diversity in coastal whaling operations: A comparison of small-scale whaling activities in Greenland, Iceland, Japan and Norway. Report from the symposium Utilisation of Marine Living Resources for Subsistence, Taiji, Japan, 20-23 January.

IUCN/UNEP/WWF. 1991. Caring for the earth. A strategy for sustainable living. Gland, Switzerland.

IWC. 1981. Report of the ad hoc technical committee working group on development of management principles and guidelines for subsistence catches of whales by indigenous (aboriginal) peoples. Cambridge: IWC/33/14.

JENTOFT, S. 1991. Hengende snøre. Fiskerikrisen og framtiden på kysten. Oslo: ad Notam.

JOHANNSEN, W. 1990. Hvalernes verden. Copenhagen: Skarv/WWF.

JOHNSON, W. 1988. The monk seal conspiracy. London: Heretic Books.

KALLAND, A. 1992. Whose whale is that? Diverting the commodity path. Maritime Anthropological Studies 5(2):in press.

KALLAND, A., and MOERAN, B. 1992. Japanese whaling: End of an era? London: Curzon Press.

KAPEL, F.O., and PETERSEN, R. 1982. Subsistence hunting - the Greenland case. In: Donovan, G.P., ed. Aboriginal/subsistence whaling. Cambridge: IWC, Special Issue No. 4.

KELLERT, S.R. 1988. Human-animal interactions: A review of American attitudes to wild and domestic animals in the twentieth century. In: Rowan, A.N., ed. Animals and people sharing the world. Hanover, NH: University Press of New England.

KLINOWSKA, M. 1988. Are cetaceans especially smart? New Scientist, 29 October:46-47.

LAWRENCE, E.A. 1986. Neotony in American perception of animals. The Journal of Psychoanalytic Anthropology 9(1):41-54.

LEVI-STRAUSS, C. 1966. The savage mind. Chicago: The University of Chicago Press.

LILLY, J.C. 1967. The mind of the dolphin: A nonhuman intelligence. New York: Doubleday. 
LINEHAN, E.J. 1979. The trouble with dolphins. National Geographic 155(4):506-540.

LORENTZ, K. 1981. The foundations of ethology. New York: Simon and Schuster.

LÖFGREN, O. 1985. Our friends in nature: Class and animal symbolism. Ethnos 50(3-4):184-213.

LYNGE, F. 1990. Kampen om de vilde dyr - en arktisk vinkling. Copenhagen: Akademisk Forlag.

MANNING, L. 1989. Marine mammals and fisheries conflict: A philosophical dispute. Ocean \& Shoreline Management 12(3):217-232.

MARINE MAMMAL NEWS. 1991. 17(5):4.

MENNINGER, K.A. 1951. Totemic aspects of contemporary attitudes toward animals. In: Wilbur, G.B., and Muensterberger, W., eds. Psychoanalysis and culture - Essays in honor of Géza Roheim. New York: International Universities Press.

MøNNESLAND, J., JOHANSEN, S., EIKELAND, S., and HANSSEN, K. 1990. Whaling in Norwegian waters in the 1980's. Oslo: NIBR-Report 1990-14.

PÁLSSON, G. 1992. Modes of production and minke whaling: The case of Iceland. In: Misaki, S., ed. The report of the symposium on the Utilization of Marine Living Resources for Subsistence. Tokyo: The Institute of Cetacean Research.

PEARSE, F. 1991. Green warriors - The people and politics behind the environmental revolution. London: The Bodley Head.

PINKERTON, E., ed. 1989. Co-operative management of local fisheries New directions for improved management and community development. Vancouver: University of British Columbia.
PRESCOTT, J.H. 1981. Clever Hans: Training the trainers. On the potential for misinterpreting the result of dolphin research. In: Sebeok, T.A., and Rosenthal, R., eds. The Clever Hans phenomenon: Communication with horses, whales, apes and people. Annals of the New York Academy of Science 364.

PRYOR, K. 1981. Why porpoise trainers are not dolphin lovers: Real and false communication in the operant setting. In: Sebeok, T.A., and Rosenthal, R., eds. The Clever Hans phenomenon: Communication with horses, whales, apes and people. Annals of the New York Academy of Science 364.

ROSE, T. 1989. Freeing the whales. How media created the world's greatest non-event. New York: Carol Publishing Group.

SANDERSON, K. 1990. Grindadráp - The discourse of drama. North Atlantic Studies 2(1-2): 196-204.

SCHEFFER, V. 1991. Why should we care about whales? In: Davies, N., Smith, A.M., Whyte, S.R., and Williams, V., eds. Why whales? Bath: Whale and Dolphin Conservation Society.

SCHWARZ, U. 1991. Umweltkonzern im Zwielicht. Geldmaschine Greenpeace. Der Spiegel 45(38) (16 September):84-105.

SINGER, P. 1990. Animal liberation. Revised ed. New York: Avon Books. TERHUNE, J. 1985. Marine survival. Policy Options Politques, May:24-26. WATSON, L. 1985. Whales of the world. London: Hutchinson.

WENZEL, G. 1991. Animal rights, human rights. Ecology, economy and ideology in the Canadian Arctic. Toronto: University of Toronto Press.

WILLIAMS, H. 1988. Whale nation. London: Jonathan Cape.

WRIGHT, G. 1984. Sons and seals - A voyage to the ice. St. John's: ISER.

WWF-DENMARK. 1990. An appeal to business executives for donations, dated 19 June. Available at Ryesgade 3F, DK-2200 Copenhagen N, Denmark. 